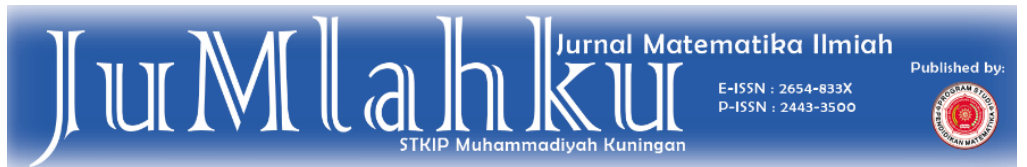

Submited: 2019-07-17

Published: 2021-12-20

\title{
DESAIN MODUL PERSAMAAN GARIS LURUS BERBASIS KOMUNIKASI MATEMATIS
}

\author{
Nafisa ${ }^{\text {a) }}$, Rochmad ${ }^{\text {) }}$ \\ a,b Universitas Negeri Semarang, Jawa Tengah
}

Corresponding Author : aulianafisa94@students.unnes.ac.id

\begin{tabular}{|c|c|}
\hline Article Info & Abstract \\
\hline $\begin{array}{l}\text { Keywords: Straight Line } \\
\text { Equation; Learning Obstacle; } \\
\text { Didcatic Design. }\end{array}$ & $\begin{array}{l}\text { Naturally, students experience a situation called learning difficulties. } \\
\text { In identifying the difficulties of students learning a material, a very } \\
\text { related factor is the epistemological barrier. Basically, students have } \\
\text { difficulty connecting the graph of straight line equations through two } \\
\text { points by determining the straight line equation through two points, } \\
\text { determining the straight line equation through one point with a certain } \\
\text { gradient, determining the gradient value through two points, restating } \\
\text { the definition and benefits of straight line equations with everyday } \\
\text { language and interpret the story problems in everyday life into } \\
\text { language and mathematical symbols. In addition, students are not } \\
\text { used to systematically solving story problems in everyday life. Thus, } \\
\text { it is necessary to have a didactic teaching material design based on } \\
\text { mathematical communication skills. This study aims to identify } \\
\text { student learning barriers related to straight line equation material and } \\
\text { describe the didactic teaching material design of straight line } \\
\text { equation material based on mathematical communication. The } \\
\text { didactic design made in the form of a straight line equation module } \\
\text { for grade VIII based on the Didactical Design Research (DDR) stage, } \\
\text { namely the didactic situation analysis stage before learning and the } \\
\text { metapedadidactic stage. At the stage of the didactic situation } \\
\text { analysis resulted in a learning obstacle, didactic anticipation of } \\
\text { teaching materials in the form of a mathematical module based on } \\
\text { mathematical communication and the results of validation of teaching } \\
\text { materials (modules) by experts. In the metapedactic stage, the } \\
\text { practicality test of teaching materials (modules) was obtained by } 10 \\
\text { grade VIII students and junior high school mathematics teachers. }\end{array}$ \\
\hline
\end{tabular}


Kata Kunci: Persamaan Garis Lurus; Learning Obstacle; Desain Didaktis.
Secara alamiah siswa mengalami situasi yang disebut dengan kesulitan belajar. Dalam mengidentifikasi kesulitan-kesulitan siswa saat mempelajari suatu materi, faktor yang sangat berkaitan adalah hambatan epistimologis. Pada dasarnya siswa mengalami kesulitan dalam menghubungkan grafik persamaan garis lurus melalui dua titik dengan menentukan persamaan garis lurus melalui dua titik, menentukan persamaan garis lurus melalui satu titik dengan gradien tertentu, menentukan nilai gradien melalui dua titik, mengungkapkan kembali definisi dan manfaat persamaan garis lurus dengan bahasa sehari-hari dan menafsirkan soal cerita dalam kehidupan sehari-hari ke dalam bahasa dan simbol matematika. Selain itu siswa belum terbiasa menyelesaikan soal cerita dalam kehidupan sehari-hari secara sistematis. Dengan demikian, perlu adanya suatu desain bahan ajar didaktis yang disusun berdasarkan kemampuan komunikasi matematis. Penelitian ini bertujuan untuk mengidentifikasi hambatan-hambatan belajar siswa terkait materi persamaan garis lurus dan mendeskripsikan desain bahan ajar didaktis materi persamaan garis lurus berbasis komunikasi matematis. Desain didaktis yang dibuat berupa modul persamaan garis lurus untuk kelas VIII berdasarkan tahapan Didactical Design Research (DDR) yaitu tahapan analisis situasi didaktis sebelum pembelajaran dan tahapan metapedadidaktik. Pada tahapan analisis situasi didaktis menghasilkan learning obstacle, antisipasi didaktis bahan ajar berupa modul matematika berbasis komunikasi matematis dan hasil validasi bahan ajar (modul) oleh para ahli. Pada tahapan metapedidaktik diperoleh uji praktikalitas bahan ajar (modul) oleh 10 siswa SMP kelas VIII dan guru matematika.

\section{PENDAHULUAN}

Komunikasi matematis merupakan suatu kemampuan untuk menyampaikan suatu gagasan/ide matematis, dan untuk memahami serta menerima suatu gagasan/ide orang lain secara cermat, analitis, kritis dan evaluatif. Siswa secara alamiah mengalami situasi yang disebut dengan kesulitan belajar. Dalam mengidentifikasi kesulitan-kesulitan siswa saat mempelajari suatu materi, faktor yang sangat berkaitan adalah hambatan epistimologis. Kesuitan siswa dalam pembelajaran matematika SMP pada materi persamaan garis lurus berdasarkan penelitian yang dilakukan oleh Tanjungsari (2012) meliputi: kesulitan dalam kemampuan menerjemahkan, kesulitan dalam menggunakan prinsip, kesulitan dalam 
menggunakan konsep dan kesulitan dalam menggunakan algoritma.

Dari hasil penelitian tersebut di atas, kesulitan siswa dilihat dari segi aljabar. Pada pembelajaran persamaan garis lurus di SMP dipelajari grafik persamaan garis lurus, gradien dan persamaan garis lurus. Ditinjau dari isi materi, garis lurus juga memuat geometri. Bisa dikatakan bahwa persamaan garis lurus merupakan bagian dari aljabar dan geometri. Siswa mengalami kesulitan dalam memahami persamaan garis lurus bukan hanya dari segi aljabar tetapi juga dari segi geometri.

Persamaan garis lurus perlu dipelajari secara utuh agar tidak ada kesalahan konsep ataupun bagian yang hilang dari konsep yang dipelajari. Dengan demikian, perlu adanya suatu proses perencanaan pembelajaran yang disusun sebagai rancangan pembelajaran berdasarkan kesulitan siswa disebut desain didaktis. Desain didaktis ini disusun berdasarkan learning obstacle yang ditemukan pada siswa. Dengan harapan bahwa desain didaktis ini dapat mengatasi hambatanhambatan belajar siswa dalam memahami materi persamaan garis lurus. Sehingga, dapat terbentuk pemahaman yang utuh pada proses berpikir siswa dan dapat mengaplikasikan konsep yang dipelajari.

Dalam pembelajaran matematika, guru mengetahui bahwa setiap siswa memiliki perbedaan dalam cara-cara belajar. Pengajaran klasikal yang menggunakan proses belajar yang sama bagi semua siswa tidak akan sesuai bagi kebutuhan dan kepribadian setiap peserta didik. Oleh karena itu diperlukan suatu media pembelajaran yang dapat membantu siswa belajar secara mandiri. Salah satu media pembelajaran yang dapat memfasilitasi belajar siswa adalah modul.

Didactical Design Research (DDR) merupakan salah satu model penelitian Design research. Model DDR ini memiliki langkah-langkah yang memudahkan peneliti dalam membuat modul yang berdasarkan kesulitan belajar yang dialami siswa. Sejalan dengan Rosita (2016) bahwa bahan ajar yang didesain berdasarkan kesulitan siswa memiliki peran penting dalam proses pencapaian tujuan pembelajaran. Menurut Suryadi (2013) bahwa, "penelitian desain didaktis pada dasarnya terdiri dari tiga tahap yaitu: (1) analisis situasi didaktis sebelum pembelajaran yang wujudnya berupa Desain Didaktis Hipotetis termasuk ADP, (2) analisis metapedadidaktik, dan (3) analisis retrosfektif yakni analisis yang mengaitkan hasil analisis situasi didaktis hipotetis dengan hasil analisis metapedadidaktik."

1. Analisis Situasi Didaktis Sebelum Pembelajaran. Pada tahap ini yang dilakukan pendidik sebelum pembelajaran berupa pemikiran pendidik tentang prediksi dan antisipasi terhadap respon siswa pada yang akan dimunculkan pada saat pembelajaran (Martadiputra, 2013).

2. Analisis Metapedadidaktik. Pada tahap ini dilakukan analisis saat pembelajaran yang dilakukan pendidik berupa kemampuan pendidik tentang peristiwa pembelajaran untuk memandang antisipasi didaktis pedagogis (ADP), hubungan didaktis (HD) dan hubungan pedagogis (HP) sebagai suatu kesatuan yang utuh seperti 
digambarkan pada segitiga didaktis yang termodifikasi.

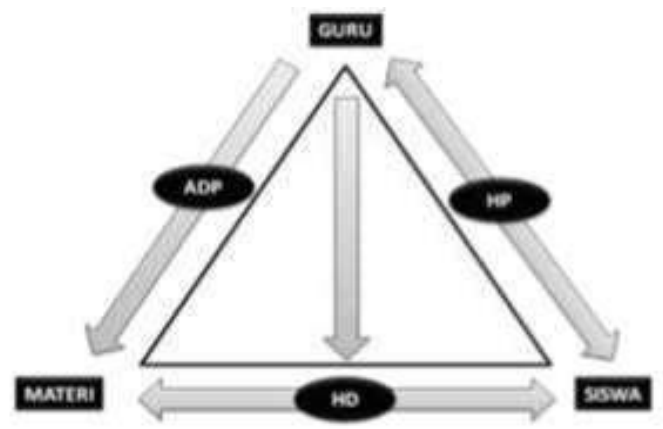

\section{Gambar 1. Situasi Analisis Metapedadidaktik}

3. Analisis Retrosfektif. Pada tahap ini pendidik menganalisis terkait hasil analisis didaktis hipotesis dengan hasil analisis metapedadidaktik berupa refleksi setelah pembelajaran.

\section{METODE}

Dalam penelitian ini, metode yang digunakan yaitu pendekatan kualitatif jenis deskriptif. Penggunaan metode penelitian kualitatif dalam penelitian bertujuan untuk menganalis hambatan belajar dan validasi bahan ajar berdasarkan learning obstacle yang dialami oleh siswa terkait materi persamaan garis lurus. Penelitian ini berdasakan tahapan Didactical Design Research (DDR). Petama, subjek identifikasi learning obstacle adalah siswa kelas IX di salah satu SMP Negeri di Kota Cirebon sebanyak 20 siswa yang sudah menerima materi persamaan garis lurus. Kedua, subjek uji praktikalitas guru dan siswa. Uji praktikalitas guru diberikan kepada seorang guru mata pelajaran matematika di salah satu SMP Negeri di Kota Cirebon dan uji praktikalitas siswa adalah 10 siswa kelas VIII di salah satu SMP Negeri di Kota Cirebon yang dipilih secara acak, sesuai dengan tingkat kemampuannya.

Teknik pengumpulan data dalam penelitian ini melalui tes uji coba instrumen, wawancara dan kuisoner (angket) berupa lembar validasi ahli dan lembar praktikalitas. Instrumen soal tes uji coba yang digunakan berupa soal kemampuan komunikasi matematis yang terdiri dari 9 soal uraian yang kemudian diidentifikasi hambatan belajarnya. Analisis butir soal yang sudah diujicobakan adalah untuk melihat validitas, reabilitas, indeks kesukaran, dan daya pembeda dari soal tersebut.

Instrumen lembar validasi ahli ini diberikan kepada ahli setelah desain bahan ajar selesai disusun. Lembar validasi ini berfungsi sebagai instrumen penelitian yang bertujuan mengetahui kriteria kevalidan desain bahan ajar. Validator ahli terdiri dari tiga ahli yaitu dua dosen yang ahli dalam bidang matematika di salah satu perguruan tinggi swasta di Cirebon dan satu guru mata pelajaran matematika di salah satu SMP Negeri di Kota Cirebon. Setelah desain bahan ajar dinyatakan cukup valid oleh ahli, selanjutnya dilakukan uji praktikalitas bahan ajar oleh pengguna.Pengguna dalam penelitian ini dibagi menjadi dua yaitu seorang guru mata pelajaran matematika 
dan 10 siswa SMP. Uji praktikalitas ini digunakan untuk mengetahui kepraktisan bahan ajar saat digunakan pada proses pembelajaran.

\section{HASIL DAN PEMBAHASAN}

Penelitian desain bahan ajar ini mempunyai tujuan untuk mengidentifikasi hambatan-hambatan belajar siswa terkait materi persamaan garis lurus dan mendeskripsikan desain bahan ajar materi persamaan garis lurus berbasis komunikasi matematis. Penelitian ini mengacu pada penelitian desain bahan ajar (Didactical Desain Research). Tahapan penelitian DDR terdiri dari tiga tahap, yaitu analisis situasi didaktis sebelum pembelajaran yang wujudnya berupa desain didaktis hipotesis termasuk ADP, analisis metapedadidaktik, dan analisis retrosfektif. Namun, pada penelitian desain didaktis ini peneliti hanya menggunakan dua tahap yaitu analisis situasi didaktis sebelum pembelajaran yang wujudnya berupa desain didaktis hipotesis termasuk ADP dan analisis metapedadidaktik.

\section{Berdasarkan}

tahapan-tahapan penelitian, maka penulis menyusun bahan ajar sesuai learning obstacle yang ditemukan saat uji coba soal. Learning obstacle yang ditemukan saat uji coba soal terkait persamaan garis lurus berbasis komunikasi matematis adalah learning obstacle tipe epistimologi, dimana pengetahuan yang dimiliki siswa terbatas pada konteks tertentu.

Berdasarkan hasil tes kemampuan komunikasi matematis yang telah dianalisis, ditemukan learning obstacle terkait materi persamaan garis lurus. Salah satu kekeliruan 144 yang sering terjadi adalah dalam penggunaan konsep menentukan persamaan garis lurus yang melalui dua titik, menentukan persamaan garis lurus yang melalui satu titik dengan gradien tertentu, menentukan nilai gradien yang melalui dua titik, dan menafsirkan soal cerita kedalam bahasa dan simbol matematika. Selain itu siswa, belum terbiasa menyelesaikan soal cerita secara sistematis. Antisipasi-antisipasi yang diberikan guru ketika pembelajaran dan disajikan pada modul yang telah dibuat, diharapkan dapat mengatasi learning obstacle yang dialami siswa terkait kemampuan komunikasi matematis pada materi persamaan garis lurus.

Desain bahan ajar persamaan garis lurus berbasis komunikasi matematis yang dibuat berupa modul matematika. Modul ini dibuat berdasarkan hambatan-hambatan belajar yang dialami siswa. Modul yang dibuat sesuai dengan tujuan pembelajaran dan tahapan pada teori Jerome S. Bruner melalui tiga tahap perkembangan kognitif (Suprijono, 2011) yaitu tahap enaktif, tahap ikonik, dan tahap simbolik. Modul ini juga memuat situasi didaktis dan antisipasi didaktis yang bertujuan untuk mengantisipasi berbagai learning obstacle yang muncul.

Tiga tahapan perkembangan kognitif menurut Bruner yang diterapkan pada modul yaitu tahap enaktif dituangkan pada pengambilan contoh soal dari kehidupan sehari-hari untuk menemukan konsep persamaan garis lurus, tahap ikonik dituangkan pada modul dalam penggunaan ilustrasi gambar untuk menanamkan konsep persamaan garis lurus, dan tahap simbolik pada modul dengan merepresentasikan 
konsep dari ilustrasi gambar ke bentuk simbol atau kata-kata.atau dibahas. Judul tabel dan grafik atau keterangan gambar disusun dalam bentuk frase (bukan kalimat) secara ringkas. Keterangan gambar/grafik diletakkan di bawah gambar/grafik tersebut, sedangkan judul tabel diletakkan di atasnya. Judul diawali dengan huruf kapital.

Susunan dalam pembuatan modul ini yaitu: a) Tujuan yang harus dicapai, yang biasanya dirumuskan dalam bentuk perilaku yang spesifik sehingga keberhasilannya dapat diukur; b) Petunjuk penggunaan, yakni petunjuk bagaimana seharusnya siswa mempelajari modul; c) Kegiatan belajar tentang materi yang harus dipelajari oleh siswa; d) Tugas atau latihan mandiri dan berdiskusi;e) Sumber bacaan atau daftar pustaka, berisi daftar buku atau sumber bacaan untuk memperdalam materi dan memperkaya wawasan siswa; g) Tes atau evaluasi, berisi soal-soal yang harus dikerjakan siswa untuk melihat keberhasilan siswa dalam menguasai materi pelajaran.

Modul yang telah disusun kemudian divalidasi oleh tiga orang ahli. Hasil validasi yang diperoleh sebesar 83,93\%, ini menunjukkan bahwa bahan ajar yang telah disusun dinyatakan cukup valid atau dapat digunakan dengan revisi kecil. Walaupun demikian, masukan-masukan dari setiap validator menjadi bahan pertimbangan untuk perbaikan bahan ajar modul.

Setelah bahan ajar dinyatakan valid oleh ahli, kemudian bahan ajar di validasi oleh pengguna. Validasi pengguna bahan ajar dilakukan menggunakan lembar praktikalitas yang diisi oleh seorang guru dan sepuluh orang siswa. Hasil lembar praktikalitas yang diisi oleh guru menunjukkan bahwa bahan ajar yang disusun termasuk kategori sangat praktis dengan presentase $85 \%$. Walaupun demikian, guru memberikan masukan yaitu tambahkan materi sifat-sifat persamaan garis lurus. Masukan ini menjadi pertimbangan dalam memperbaiki bahan ajar. Hasil lembar praktikalitas gabungan yang diisi oleh siswa menunjukkan presentase 82,92\% termasuk kategori sangat praktis. Komentar yang diberikan siswa menjadi pertimbangan dalam memperbaiki bahan ajar. Namun secara keseluruhan siswa memberikan tanggapan positif terhadap modul ini.

\section{PENUTUP}

\section{Simpulan}

Berdasarkan hasil analisis yang telah dilakukan, maka dapat disimpulkan bahwa dalam mendesain suatu bahan ajar persamaan garis lurus berbasis komunikasi matematis, ada beberapa langkah sesuai metode desain bahan ajar. Adapun tahapan berdasarkan tahapan Didactical Design Research (DDR) dalam mendesain bahan ajar pada materi persamaan garis lurus tersebut adalah sebagai berikut.

1. Pada tahapan analisis situasi didaktis sebelum pembelajaran menghasilkan:

a) Learning obstacle setelah hasil uji coba soal dianalisis. Learning obstacle yang dialami siswa khususnya learning obstacle tipe epistimologis. Adapun hambatan epistimologis yang sering terjadi pada materi persamaan garis lurus yaitu hambatan konseptual dan hambatan prosedural. Hambatan konseptual yang sering terjadi pada 
materi persamaan garis lurus terkait dalam menghubungkan grafik persamaan garis lurus melalui dua titik dengan menentukan persamaan garis lurus melalui dua titik; penggunaan rumus yang tidak sesuai dalam menentukan nilai gradien melalui dua titik dan persamaan garis lurus; dan tidak sesuainya definisi dan manfaat yang diungkapkan kembali dengan konsep definisi yang ada mengenai persamaan garis lurus dan gradien. Sedangkan hambatan prosedural yang sering terjadi pada materi persamaan garis lurus yaitu tidak sesuainya langkah penyelesaian soal yang diperintahkan dengan langkah penyelesaian soal yang dilakukan siswa.

b) Setelah menganalisis learning obstacle, disusunlah antisipasi didaktis berupa modul matematika berbasis komunikasi matematis berdasarkan teori belajar Bruner. Teori belajar Bruner memiliki tiga tahapan, yaitu tahapan enaktik, ikonik dan simbolik.

c) Kemudian bahan ajar berupa modul tersebut divalidasi oleh ahli. Validasi bahan ajar ini dilakukan oleh 3 ahli yang terdiri dari dua dosen pendidikan matematika dan satu guru mata pelajaran matematika. Berdasarkan hasil validasi dari ketiga ahli diperoleh presentase sebesar $83,93 \%$ dengan tingkat validasi cukup valid dan bahan ajar persamaan garis lurus berbasis komunikasi matematis layak digunakan dalam pembelajaran matematika pada materi persamaan garis lurus dengan revisi kecil.

2.Pada tahapan metapedidaktik menghasilkan validasi bahan ajar oleh pengguna yaitu uji praktikalitas bahan ajar (modul). Validasi pengguna ini dilakukan oleh seorang guru mata pelajaran matematika dan 10 siswa SMP yang dipilih secara acak sesuai tingkat kemampuannya. Data validasi pengguna diperoleh melalui uji praktikalitas. Berdasarkan hasil uji praktikalitas yang diisi oleh guru diperoleh persentase sebesar $85 \%$ dengan tingkat kepraktisan yaitu sangat praktis. Sedangkan berdasarkan hasil uji praktikalitas yang diisi oleh siswa diperoleh presentase sebesar 82,92\% dengan tingkat kepraktisan yaitu sangat praktis. Dari dua hasil uji praktikalitas ini menunjukkan bahwa bahan ajar persamaan garis lurus berbasis komunikasi matematis sangat praktis digunakan dalam pembelajaran matematika pada materi persamaan garis lurus.

\section{Saran}

Berdasarkan simpulan hasil penelitian yang telah dibahas sebelumnya, disarankan hal-hal berikut:

1. Untuk pengembangan penelitian, penulis menyarankan untuk menganalisis learning obstacle dengan ruang lingkup yang lebih luas agar diperoleh learning obstacle yang lebih beragam.

2. Modul persamaan garis lurus dapat dijadikan sebagai alternatif bahan ajar yang dapat mengembangkan kemampuan komunikasi matematis siswa pada indikator menghubungkan 
benda nyata, gambar, dan diagram ke dalam ide matematika, menjelaskan ide situasi dan relasi matematis secara lisan atau tulisan dengan benda nyata, gambar, grafik dan aljabar, menyatakan peristiwa sehari-hari dalam bahasa atau simbol matematika, dan mengungkapkan kembali suatu uraian atau paragrap matematika dalam bahasa sehari-hari.

3. Mengembangkan modul persamaan garis lurus berbasis komunikasi matematis dapat menjadi salah satu alternatif bagi guru untuk meningkatkan pemahaman konsep siswa dan pembaharuan dalam pembelajaran matematika.

\section{DAFTAR PUSTAKA}

Akbar, S. (2013). Instrumen Perangkat Pembelajaran. Bandung: PT Remaja Rosdakarya.

Arikunto, S. (2012). Dasar-dasar Evaluasi Pendidikan. Jakarta: Bumi Aksara.

Cahyo, A. (2013). Panduan Teori Aplikasi Belajar Mengajar. Yogyakarta: Diva Press.

Euis, S. (2011). Hambatan Epistimologis (Epistimological Obstacle) dalam Persamaan Kuadrat Pada Siswa Madrasah Aliyah : International Seminar and the Fourth National Conference on Mathematics Education. Yogyakarta.

Hamzah, A. (2014). Evaluasi Pembelajaran Matematika. Jakarta: PT Raja Grafindo Persada.
Hendriana dan Soemarmo. (2014). Penelitian Pembelajaran Matematika. Bandung: PT Reflika Aditama.

Isjoni. (2016). Cooperative Learning (Efektivitas Pembelajaran Kelompok). Bandung: Alfabeta.

Lestari dan Yudhanegara. (2015). Penelitian Pendidikan Matematika. Bandung: PT Reflika Aditama.

Lidinillah, D. (2012). Design Research Sebagai Model Penelitian Pendidikan: a theoretical framework for action. Tasikmalaya : PGSD UPI.

Nisa dan Fardatun. (2010). Analisis Kesalahan Siswa Kelas VIII SMP Kemala Bhayangkari Surabaya dalam Menyelesaikan Soal Cerita pada Materi Bangun Ruang. Skripsi UNESA Surabaya.

Prastowo, A. (2015). Panduan Kreatif Membuat Bahan Ajar Inovatif. Yogyakarta: Diva Press.

Rosita, C.D. (2016). The Development Of Courseware Based On Mathematical Representations And Arguments In Number Theory Courses. Journal of Mathematics Education Volume 5, No. 2.

Sagala, S.( 2012). Konsep dan makna pembelajaran. Bandung: Alfabeta.

Sanjaya, W. (2008). Perencanaan dan Desain Sistem Pembelajaran. Bandung: Prenadamedia Group.

Sugiyono. (2017). Metode Penelitian Pendidikan (Pendekatan Kuantitatif, Kualitatif, dan R\&D). Bandung: Alfabeta.

Sukmadinata, N.N. (2012). Metode Penelitian Pendidikan. Bandung : PT Remaja Rosdakarya. 
Suprijono. (2012). Cooperative Learning, Teori dan aplikasi PAIKEM. Yogyakarta: Pustaka Pelajar.

Suryadi, D. (2010). Menciptakan Proses Belajar Aktif : Kajian Sudut Pandang Teori Belajar Didaktik. Bandung: Jurnal Pendidikan Matematka FMIPA UPI.

Suryadi, D. 2010. Model Antisipasi dan Situasi Didaktis Dalam Pembelajaran Matematika Kombinatorik Berbasis Pendekatan Tidak Langsung. Bandung: Jurnal Pendidikan Matematka FMIPA UPI.

Suryadi, D. (2010). Penelitian Pembelajaran Matematika untuk Pembentukan Karakter Bangsa.Seminar Nasional Matematika dan Pendidikan Matematika Yogyakarta.polyantum) sebagai antibakteri Escherichia coli. J. Media Peternakan. 30(1): 55-62.

Suryadi, D. (2013). Didactical Design Research (DDR) dalam Pembelajaran Matematika.Prosiding Seminar Nasional Matematika dan Pendidikan Matematika STKIP Siliwangi Bandung.Vol 1, 2013. ISSN 977-2338831.

Tanjungsari, R.D. (2012). Diagnosis Kesulitan Belajar Matematika SMP Pada Materi Persamaan Garis Lurus.

Yaumi, M. (2013). Prinsip-prinsip Desain Pembelajaran Disesuaikan dengan Kurikulum 2013 Edisi Kedua. Jakarta: Kencana. 